\title{
Pengembangan Smart Home System Berbasis Kecerdasan Buatan untuk Memanajemen Konsumsi Energi Rumah Tangga dengan Pendekatan Finansial \\ ${ }^{1}$ Ihsan Auditia Akhinov, ${ }^{2}$ Muhammad Ridwan Arif Cahyono \\ 1,2Politeknik Gajah Tunggal, Indonesia \\ I'ihsan@poltek-gt.ac.id; ${ }^{2}$ ridwan@poltek-gt.ac.id;
}

\section{Article Info}

Article history:

Received, 16-12-2020

Revised, 16-12-2020

Accepted, 28-12-2020

\section{Kata Kunci:}

Internet of Things (IoT) Artificial Neural Network (ANN) Aplikasi Android Smart Home

\section{ABSTRAK}

Teknologi rumah pintar yang dikembangkan saat ini belum sepenuhnya mampu mendukung program konservasi energi yang dicanangkan pemerintah. Selain Saat ini kontrol untuk pengaturan rumah pintar masih dilakukan secara manual, belum sepenuhnya otomatis. Pada penelitian ini akan dibangun sistem rumah pintar yang dikendalikan oleh kecerdasan buatan untuk mengendalikan pemakaian energi berdasarkan besaran nilai tagihan bulanan. ESP32 digunakan sebagai perangkat Internet of Things (IoT) yang berfungsi mendeteksi keberadaan manusia dan mengukur energi listrik yang dikonsumsi. Data-data tersebut disimpan dalam online web server yang dibangun dari Raspberry Pi. Sistem ini dapat dimonitor dan dikendalikan oleh aplikasi berbasis Web. Aplikasi ini sudah diuji dengan menggunakan metode Black Box, hasilnya $100 \%$ aplikasi berjalan lancar. Artificial Neural Network diimplementasikan menggunakan bahasa Python, dengan 4 input, 2 layer, dan 4 output dimana masing-masing layer terdiri dari 4 neuron. Variabel masukan yang digunakan dalam ANN yaitu intensitas cahaya, temperatur ruangan, durasi waktu penggunaan ruangan, dan target biaya bulanan, sedangkan keluaran dari ANN ini yaitu durasi penggunaan peralatan listrik, dalam purwarupa ini yaitu durasi penggunaan AC, TV, refrigerator, dan lampu. Sistem sudah mampu berjalan dengan baik, mampu memberikan rekomendasi durasi maksimal penggunaan peralatan listrik dengan tingkat kesalahan sebesar 1,64\%.

\section{ABSTRACT}

The smart home technology currently being developed is not fully capable of supporting the government's energy conservation program. Apart from this, the controls for smart home settings are still manually, not fully automatic. In this study, a smart home system controlled by artificial intelligence will be built to handle energy consumption based on the monthly bill. ESP32 is used as an Internet of Thing (IoT) device to detect human presence and measure the electrical energy consumed. The data is stored on an online web server built from the Raspberry Pi. This system can be monitored and controlled by an Android application. This application has been tested using the Black Box method; the results are $100 \%$ running smoothly. Artificial Neural Network is implemented using python language, with four inputs, two layers, and four outputs, where each layer consists of four neurons. The input variables used in ANN are light intensity, room temperature, room usage, time duration, and monthly cost target. Simultaneously, the output of this ANN is the duration of the use of electrical equipment. In this prototype, the period of use of air conditioner, TV, refrigerator, and light. The system can run properly and provide recommendations for the maximum duration of use of electrical equipment with an error rate of $1.64 \%$.

This is an open access article under the CC BY-SAlicense.

\section{Penulis Korespondensi:}

Ihsan Auditia Akhinov, Program Studi Teknik Elektronika, Politeknik Gajah Tunggal, Email: ihsan@poltek-gt.ac.id 


\section{PENDAHULUAN}

Sesuai dengan Peraturan Pemerintah Nomor 70 Tahun 2009 tentang konservasi energi, bagian pokok konversi energi meliputi adanya audit energi yaitu mengetahui profil penggunaan energi, mengidentifikasi pemborosan energi dan menyusun langkah pencegahannya. Salah satu sektor yang wajib melakukan pengelolaan energi yaitu sektor rumah tangga. Sektor rumah tangga merupakan salah satu pengguna final energi listrik.

Rumah tangga merupakan salah satu sektor dengan konsumsi energi $12 \%$ dari konsumsi energi total seluruh sektor di Indonesia, dimana porsi tertinggi digunakan pada sektor industri sebesar 50\% [1]. Di dalam rumah tangga terdapat banyak peralatan elektronik yang dalam pemakaiaanya mengkonsumsi energi listrik. Akan tetapi, konsumsi energi di kalangan rumah tangga tergolong boros. Hal ini dikarenakan masyarakat belum bisa mengatur konsumsi energi listrik di dalam rumah tangga dengan baik. Selain itu, belum adanya sistem yang tepat untuk diterapkan pada rumah tangga juga menjadi salah satu penyebab tingginya tingkat keborosan penggunaan energi dalam rumah tangga.

Smart Home merupakan perpaduan antara teknologi informasi dan teknologi komputasi yang di terapkan di dalam rumah ataupun bangunan yang dihuni oleh manusia dengan mengandalkan efisiensi, otomatisasi perangkat, kenyamanan, keamanan, dan penghematan perangkat elektronik rumah. Sesuai dengan perkembangan teknologi, saat ini produksi smart home sudah banyak berkembang dengan berbagai macam konsep dan sistem yang di bangun. Smarthome merupakan sistem yang telah diprogram dan dapat bekerja dengan bantuan komputer untuk mengitegrasikan dan mengendalikan sebuah perangkat atau peralatan rumah secara otomatis dan efisien.

Model Smart home yang pernah dikembangkan sebelumnya adalah sistem kontrol lampu, kontrol kipas, dan kontrol alat pengusir nyamuk secara otomatis [2]. Perangkat ini secara otomatis akan ketika menyalakan komponen listrik tersebut, saat pengguna masuk ke dalam ruangan menggunakan perangkat arduino Uno. Selain itu desain sistem pengendali lampu dan perangkat listrik yang diusulkan berfungsi untuk meniru keberadaan penghuni rumah saat rumah dalam keadaan kosong [3]. Pada penelitian [4], juga dikembangkan sistem ON/OFF lampu penerangan berdasarkan keberadaan manusia. Sistem ini berbasis NodeMCU ESP8266 dan dilengkapi dengan sensor PIR sebagai perangkat untuk pengaman rumah. Sistem ini menggunakan database MySQL dengan perantara komunikasi menggunakan bahasa PHP.

Model Smart Home lainnya dibangun dengan Rasberry Pi sebagai pengendali pusat. Rasberry Pi mengendalikan saluran irigasi pada kebun rumah sesuai dengan data pada sensor kelembaban tanah, sensor cahaya dan sensor jarak. Komunikasi data antara smartphone dengan Rasberry Pi mengunakan komunikasi wireless yang bersifat lokal [5]. Pada penelitian [6], dikembangkan skenario perancangan sistem Home Energy Management System (HEMS) baik dari segi hardware dan algoritma pengaturan management energi. Pada penelitian [3], penelitian ini melakukan implementasi smart home dengan menggunakan sistem pengontrolan biasa tanpa melibatkan kecerdasan buatan.

Tantangan teknologi kedepan adalah sistem rumah pintar harus mampu mengendalikan konsumsi penggunaan energi pada rumah tersebut. Dari beberapa penelitian yang sudah dilakukan sebelumnya, masih terdapat gap teknologi dimana pengendalian konsumsi energi di rumah tangga belum sepenuhnya otomatis. Penelitian ini akan merancang sistem rumah pintar berbasi Internet of Thing (IoT) yang dikendalikan oleh kecerdasan buatan Artificial Neural Network (ANN) untuk mengendalikan pemakaian energi sesuai dengan target finansial berupa besaran tagihan bulanan. Sistem kecerdasan buatan ini akan mampu menyalakan dan mematikan komponen listrik secara otomatis.

\section{METODE PENELITIAN}

Metode pada penelitian ini diawali dengan menyimpan data-data yang dihasilkan oleh beberapa sensor dengan mikrokontroler sebagai pembaca nilai ouput dan mengirimkan data tersebut kedatabase melalui jaringan internet. Database yang digunkan adalah Mysql yang ditanamkan pada raspberrry. Penggunaan raspberry pi 4 tidak hanya sebagai penyimpanan data akan tetapi juga sebagai pengolah dan pemprosesan data-data yang diterima. Pengolahan tersebut melibatkan Artificial Neural Network (ANN). Hasil pengolahan ANN akan menghasilkan rekomendasi parameter yang dibutuhkan yang dapat dilihat serta diatur melalui smartphone.

Aplikasi sistem cerdas ini menggunakan Raspberry Pi versi 4 yang berfungsi sebagai online web server yang akan menghubungkan antara hardware dan software yang dikontrol melalui aplikasi web sebagai interface yang digunakan pengguna untuk memasukan input dan menghasilkan output. Pada aplikasi berbasis web tersebut juga akan dilaporkan penggunaan energi listrik, sehingga dapat termonitor dengan baik. 
Selain itu juga akan dirancang hardware Internet of Things berbasis Arduino yang berisi Occupancy Sensor, PIR sensor, sensor temperatur dan photo sensor yang berfungsi mendeteksi keberadaan manusia dan dipasang sensor energi listrik untuk mencatat penggunaan daya listrik. Selain itu digunakan pengguna dapat memasukan target tagihan listrik bulanan dan kecerdasan buatan akan memberikan rekomendasi penggunaan energi listrik, sistem cerdas ini akan mengatur penggunaan komponen listrik berdasarkan target tagihan listrik bulanan yang ditetapkan. Penekanaan utama pada artikel ini adalah pada sistem kontrol ANN.

Secara detail langkah-langkah dalam penilitian ini yang melibatkan konsep Smarthome System dan Artificial Neural Network (ANN) sebagai berikut :

\subsection{Smarthome System}

Smart home system telah banyak dikembangkan untuk memudahkan manusia dalam melakukan aktivitas sehari. Smart home sistem tersebut terdiri dari beberapa landasan teori yang mengintegrasikan beberapa alat dengan mempunyai tujuan tertentu berdasarkan kecerdasan buatan yang ditanam pada perangkat keras [7].

Beberapa kondisi harus terpenuhi dalam penerapan smart home system ini adalah Sistem Kontrol dan Artificial Intellegence. Sistem Kontrol adalah sebuah metoda untuk mengendalikan/memerintah output yang diinginkan, dengan bantuan sensor-sensor. Output dari sebuah sensor berupa nilai, dalam hal ini nilai tersebut dapat digunakan untuk memenuhi tujuan yang diinginkan. Sedangkan untuk sistem kontrol tersebut dapat berupa ANN [7].

Aplikasi smart home yang dikembangkan mengikuti flowchart seperti pada Gambar 1. Aplikasi ini berfungsi untuk melakukan pemantauan dan pengendalian pada sistem smart home. Aplikasi ini terdiri dari beberapa menu utama diantaranya Menu Control, Menu Monitor, Menu Sistem ANN, dan Menu History.

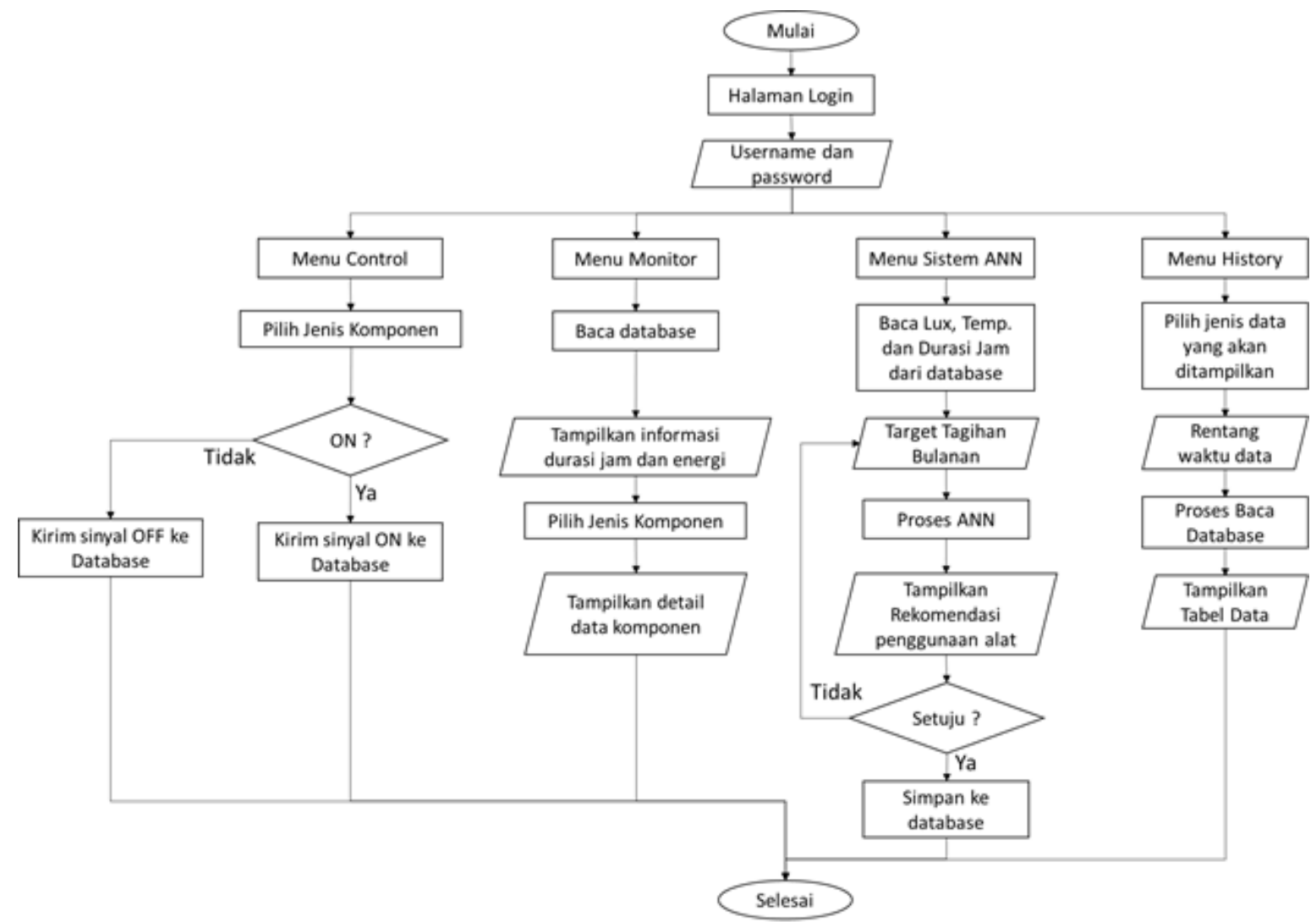

Gambar 1. Flowchart sederhana aplikasi

Aplikasi tersebut menggunakan database MySQL yang disimpan dalam web server dalam Arduino. Beberapa tabel yang digunakan ditunjukan seperti pada Tabel 1, Tabel 2, dan Tabel 3. Tabel 1 menunjukan data penggunaan komponen listrik. Data ini diambil dari smart watt meter yang digunakan untuk memonitor dan mengendalikan penggunaan energi listrik. Alat ini mampu untuk mengukur tegangan (volt), arus (ampere), daya (watt), energi (wh), frekuensi (Hz), dan factor daya. Selain itu juga terdapat sensor Cahaya, sensor temperatur, dan sensor okupansi yang berfungsi untuk mendeteksi manusia. Data disimpan ke dalam database setiap detik. 
Pada Tabel 2 digunakan untuk menentukan status ON dan OFF dari peralatan listrik yang digunakan. Dalam Penelitian ini digunakan 4 jenis komponen listrik berupa Air Conditioner (AC), lampu, Television (TV), dan refrigerator. Apabila komponen menyala, maka status bernilai 1 (satu), apabila komponen mati, maka status bernilai 0 (nol). Pada Tabel 3 merupakan hasil keluaran dari sistem ANN. Data ini yang menjadi acuan untuk menentukan ON atau OFF komponen.

Tabel 1. Komponen Database Tabel "history_usage"

\begin{tabular}{lll}
\hline Nama Field & Tipe & Keterangan \\
\hline id & Int & No urut data \\
id_komponen & Varchar & Jenis Komponen \\
volt & Double & Tegangan (V) \\
current & Double & Arus (A) \\
power & Double & Daya (W) \\
energy & Double & Energi (Wh) \\
frequency & Double & Frekuensi (Hz) \\
pf & Double & Faktor Daya \\
lux & Double & Intensitas Cahaya \\
temp & Double & Temperatur Ruangan \\
occupancy & Int & Penggunaan Ruang \\
waktu & Timestamp & Tanggal penyimpanan data \\
\hline
\end{tabular}

Tabel 2. Komponen Database "component_status"

\begin{tabular}{lll}
\hline Nama Field & Tipe & Keterangan \\
\hline id & Int & No urut data \\
nama_component & Varchar & Nama Komponen \\
status & Int & Menyatakan ON/OFF peralatan \\
\hline
\end{tabular}

Tabel 3. Komponen Database "rekomendasi_penggunaan"

\begin{tabular}{lll}
\hline Nama Field & Tipe & Keterangan \\
\hline id & Int & No urut data \\
komponen & Text & Nama Komponen \\
durasi & Double & Durasi penggunaan komponen \\
energi & Double & Batas total energi \\
\hline
\end{tabular}

\subsection{Neural Network}

Artificial Neural Network (ANN) merupakan model penalaran yang didasarkan pada otak manusia. Penalaran ANN berdasarkan history atau data training yang diberikan ke algoritma ANN. ANN terdiri dari perceptron dan neuron. Perceptron bisa dikategorikan sebagai masukan atau juga bisa disebut input vector, sedangkan neuron adalah hasil sebuah matematis pengalian dan penjumlahan berupa persamaan 1 [8].

$$
n=(\boldsymbol{W} * p+\boldsymbol{B})
$$

$$
\begin{array}{ll}
n=\text { neuron } & \boldsymbol{W}=\text { Weight matriks } \\
p=\text { perceptron } & \boldsymbol{B}=\text { Bias matriks }
\end{array}
$$

Neuron ini akan diteruskan sebagai masukan untuk sebuah fungsi dengan keluaran berupa output vector[9]. Fungsi(f) yang digunakan dalam penelitian ini adalah fungsi log-sigmoid seperti pada persamaan 2 dan fungsi linear pada persamaan 3.

$$
\begin{aligned}
& a_{\text {logsig }}=\frac{1}{1+e^{-n}} \\
& a_{\text {purelin }}=n
\end{aligned}
$$

Untuk menentukan kelompok data dengan kondisi yang bersifat nonlinear, maka dibutuhkan beberapa layer dalam mengkategorikan input tersebut yang sesuai dengan target/output yang diinginkan [10]. Hal ini bisa dilihat pada Gambar 2, yang mana menunjukkan bahwa penggunaan beberapa layar salah satu mencari solusi dari data input yang kompleks. 


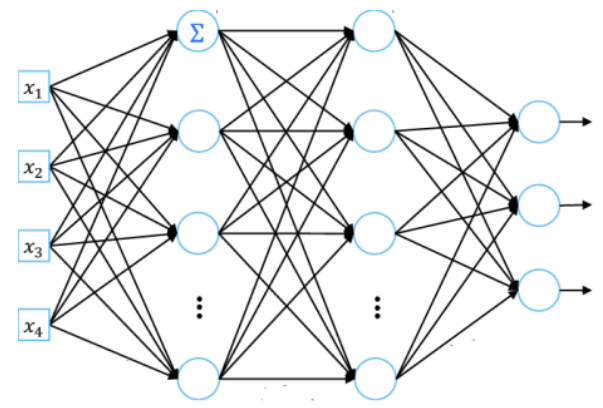

Gambar 2. Neural Network 2 Hidden Layer.

Layer ini juga dikenal dengan hidden layer. Menentukan nilai $\mathbf{W}$ seperti pada persamaan 6 dan $\mathbf{B}$ seperti pada persamaan 7, yang sesuai menggunakan solusi Back Propagation(BP) [11]. Metoda ini membutuhkan nilai Sensitifity(s) tiap layer yang dihitung dalam persamaan 4 dan 5 dan juga learning rate( $(\alpha)$. Untuk $\dot{F}$ merupakan turunan dari fungsi yang sedang diproses dan dalam bentuk matriks diagonal, dimensi matriks in tergantung dari dimensi perkalian sebelumnya. Jika matriks (t-a) menghasilkan dimensi baris x kolom maka dimensi matriks $\dot{F}$ menjadi baris x baris seperti pada persamaan 8. Hal tersebut berlaku juga untuk yang lain. Mengimbangi pengalian matriks sebelumnya, sehingga dapat diproses secara dot product antar matriks [12].

$$
\begin{aligned}
& \boldsymbol{s}^{M}=-2 \boldsymbol{F}^{M}\left(\dot{n}^{M}\right)(\boldsymbol{t}-\boldsymbol{a}) \\
& \boldsymbol{s}^{m}=-2 \boldsymbol{F}^{m}\left(\dot{n}^{m}\right)\left(\boldsymbol{W}^{m+1}\right) \boldsymbol{s}^{m+1} \\
& \boldsymbol{W}^{m}(k+1)=\boldsymbol{W}^{m}(k)-\alpha \boldsymbol{s}^{m}\left(\boldsymbol{a}^{m-1}\right)^{T} \\
& \boldsymbol{B}^{m}(k+1)=\boldsymbol{B}^{m}(k)-\alpha \boldsymbol{s}^{m} \\
& \boldsymbol{F}^{m}\left(n^{m}\right)=\left[\begin{array}{ccc}
f^{m}\left(n_{1}^{m}\right) & \cdots & 0 \\
\vdots & \ddots & \vdots \\
0 & \cdots & f^{m}\left(n_{s^{m}}^{m}\right)
\end{array}\right]
\end{aligned}
$$

$$
\begin{aligned}
& 0<\alpha<1 \\
& M \quad=\text { Banyak layer } \\
& m \quad=M-1
\end{aligned}
$$

Pada ANN terdapat dua siklus yaitu siklus dalam training (Gambar 3.a) dan siklus dalam penggunaan (Gambar 3b). Untuk siklus training menghasilkan weight dan bias matriks yang nantinya akan digunakan oleh siklus penggunaan. Siklus penggunaan akan mencari nilai root mean square error (RMSE) terhadap output/target pada training. Nilai RMSE yang kecil akan mengindikasikan hasil dalam siklus penggunaan mendekati kelompok ouput/target training. Pemilihan data training menentukan nilai RMSE hasil dari ANN. Oleh karena itu perlu beberapa kali pengujian dari segi input, iterasi, dimensi Weight matriks dan juga bias matriks [13].

Pada proses siklus training parameter sensitivity(S -persamaan 4) mengandung derivative untuk layer terakhir. Jika purelin (persamaan 3) $\mathrm{a}=\mathrm{n}$ diturunkan terhadap $\mathrm{n}$ maka menjadi 1 (konstanta). Sedangkan untuk layer 1, turunan dari logsig (persamaan 2) menjadi persamaan 9.

$$
\dot{f}(n)=\left(1-\frac{1}{1+e^{-n}}\right)\left(\frac{1}{1+e^{-n}}\right)
$$

Dimensi Weight dan Bias matriks tiap layer yang digunakan pada penilitian ini dilakukan beberapa pengujian dari dimensi weight $4 \times 4$ sampai dengan $8 \times 4$ untuk layer pertama, dan layer kedua serta bias masing-masing layer mengimbangi hasil perkalian matriks pertama sehinga dapat dijumlah dan dikalikan kembali sesuai dengan persamaan (1) dan (2) [14]. Dimensi hasil tersebut nantinya menentukan dimensi/atau jumlah neuron yang dilibatkan. 
Jika perkalian matriks pada persaaman (2) $\mathbf{W} * \mathbf{p}$ dengan dimensi weight $4 \mathrm{x} 4$, karena $\mathrm{p}=$ masukan dengan dimensi $1 \times 4$ untuk dapat dikalikan maka perlu dilakukan transpose. Hasil dimensi neuron pada layer pertama dan kedua adalah $4 \times 1$,Sehingga nantinya matrik turunan pada sensitiviy menjadi $4 \times 4$ dengan kententuan berupa matriks diagonal [15].

Pemograman perkalian serta pembentukan matriks (jumlah neuron) dalam bahasa python dapat dipersingkat berdasarkan perkalian matriks. Perkalian tiap elemen pada matriks turunan dengan berupa diagonal matriks, dapat dipersingkat langsung menjadi perkalian antar elemen tanpa harus membentuk matriks diagonal. Nilai RMSE dari hasil tiap-tiap iterasi disimpan begitu juga dengan nilai $\mathbf{W}$ dan $\mathbf{B}$. Nantinya akan digunakan nilai $\mathbf{W}$ dan $\mathbf{B}$ tiap layer yang mempunyai nilai RMSE terkecil.

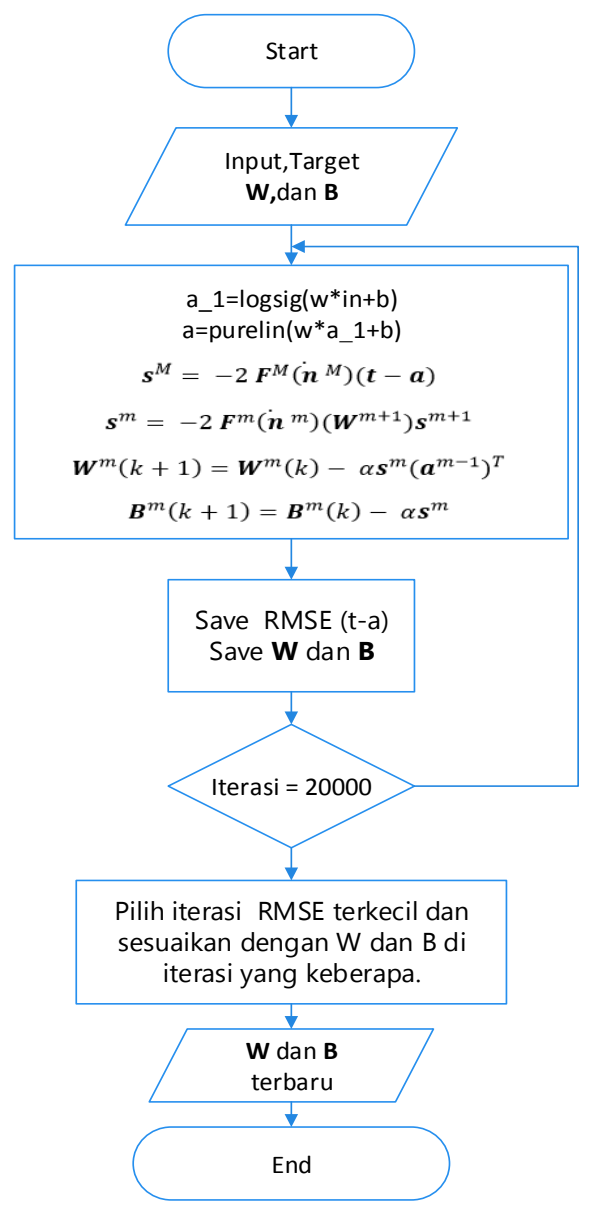

(a)

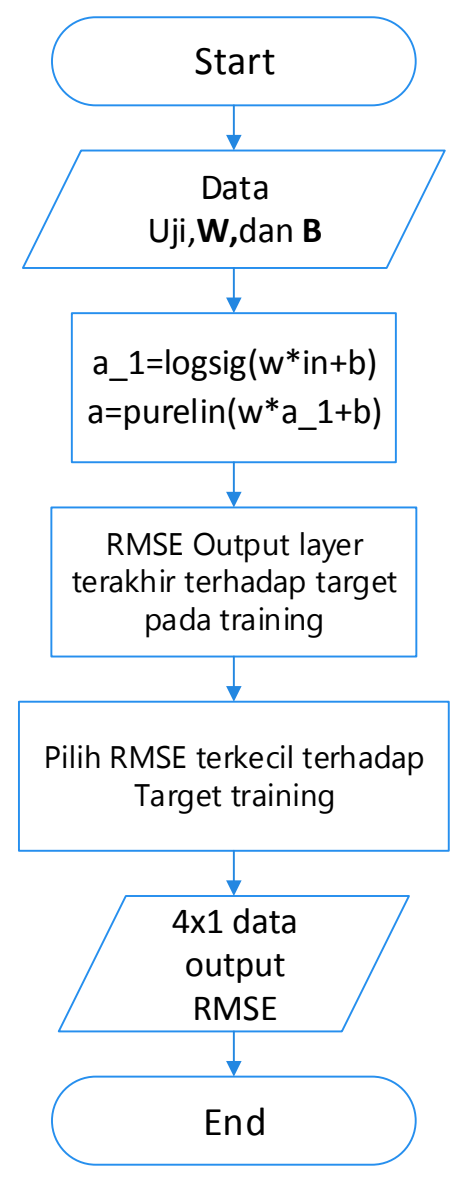

(b)

Gambar 3. (a)Diagram Alir Siklus Training ANN, (b) Diagram Alir Siklus Penggunaan ANN

Siklus penggunaan hanya memanfaatkan nilai $\mathbf{W}$ dan $\mathbf{B}$ tiap layer dari hasil training. Output dari layer terakhir akan digunakan untuk mencari nilai RMSE dari output training. Nilai RMSE yang terkecil menunjukan bahwa data inputan mempunyai kedekatan antara data output training dengan RMSE yang rendah. RMSE yang rendah menghasilkan akurasi yang tinggi [16].

\section{HASIL DAN ANALISIS}

\subsection{Gambaran Umum Alat}

Konfigurasi umum sitem yang terdapat pada Gambar $4 \mathrm{a}$, dimana masing-masing komponen peralatan listrik terhubung dengan IoT : Smart Meter + Relay. Pada Gambar 4b, ditunjukan komponen detail pada alat IoT tersebut, yang terdiri dari relay, sensor suhu, sensor energi, sensor Okupansi, sensor cahaya dan juga mikroprosesor berupa perangkat EPS32. Perangkat ESP32 dipilih karena sudah terdapat perangkat wifi dalam mikroprosesor tersebut. Hal ini bertujuan sebagai pembaca data sensor, mengirim data sensor, serta melakukan aksi pemutusan dan penyambungan jaringan listrik sesuai perintah yang dikirimkan oleh program ANN yang terdapat di Raspberry Pi. Untuk monitoring dan pengaturan sistem dapat diatur melalui aplikasi android yang terdapat pada smart phone. 


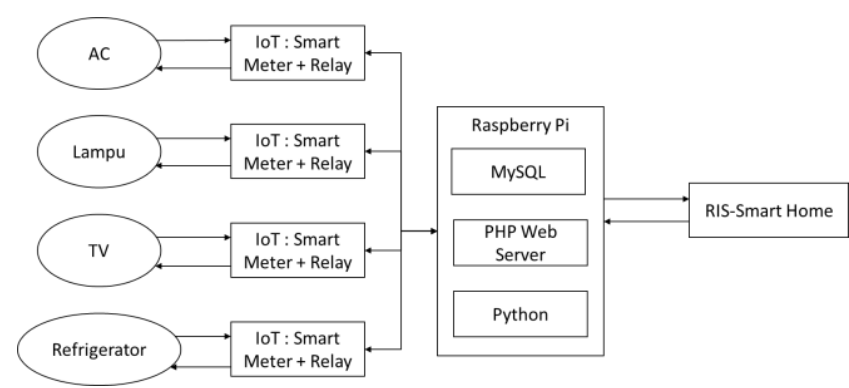

(a)

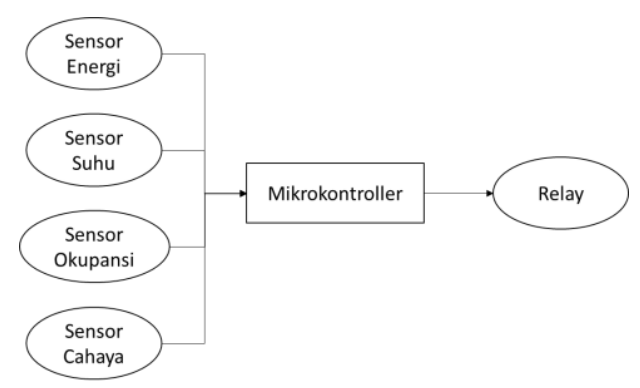

(b)

Gambar 4. (a) Konfigurasi umum alat, (b) Skema diagram IoT : Smart Meter + Relay

\subsection{Aplikasi RIS-Smart Home}

Aplikasi "RIS - Smart Home" berhasil dibangun berbasis web base dan diubah menjadi aplikasi android dengan menggunakan aplikasi APPInventor v2. Untuk dapat mengakses ke aplikasi tersebut diperlukan autentikasi dengan melakukan Login tersebih dahulu. Halaman Login ditunjukan seperti pada Gambar 5a. Setelah Login berhasil akan masuk ke dalam halaman Monitoring Beban Listrik seperti ditunjukan pada Gambar 5b. Pada Gambar 5b tersebut ditunjukan perkiraan durasi total penggunaan peralatan listrik dalam 1 bulan, durasi sisa yang dapat digunakan, total durasi yang sudah digunakan, dan total tagihan listrik dalam periode tersebut. Apabila akan berganti halaman dapat dilakukan dengan menekan menu di sebelah kiri atas. Daftar tampilan Menu ditunjukan seperti pada Gambar 5c. Pada Menu Monitoring Beban Listrik, apabila dipilih salah satu komponen litrik, maka akan ditampilkan data detail tentang status komponen tersebut seperti ditunjukan pada Gambar 6a, data yang ditampilkan dalam Gambar 6a meliputi status peralatan (ON / OFF), tegangan, arus, daya, energi, frekuensi, dan factor daya. Pada Gambar 6b ditunjukan menu Kontrol Beban Listrik. Menu ini berfungsi untuk melakukan pengaturan ON atau OFF komponen secara manual. Pada Gambar 6c, ditunjukan halaman Riwayat Pengggunaan. Untuk menampilkan data tersebut, sebelumnya harus dipilih jenis komponen dan rentang tanggal yang akan ditampilkan datanya. Hasil data ditampilkan dalam bentuk grafik dan tabel.

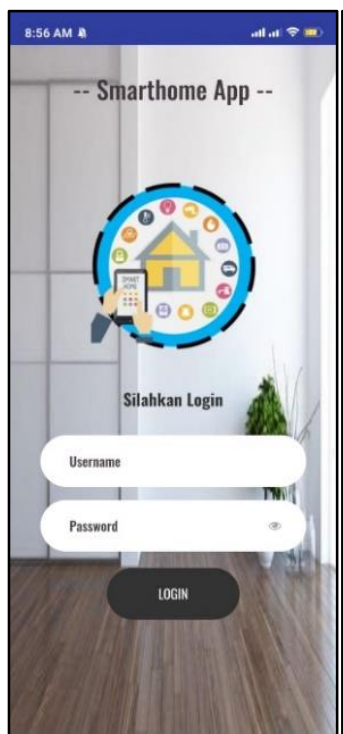

(a)

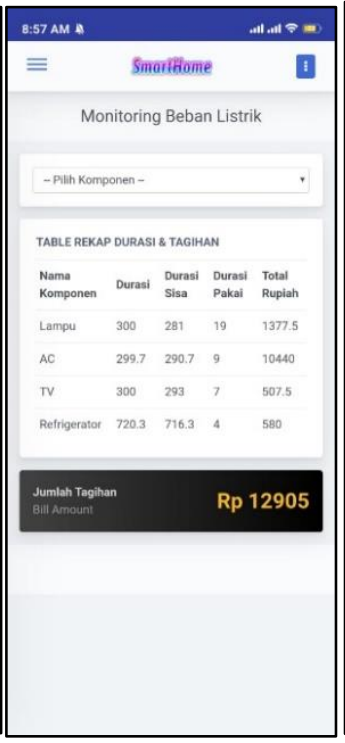

(b)

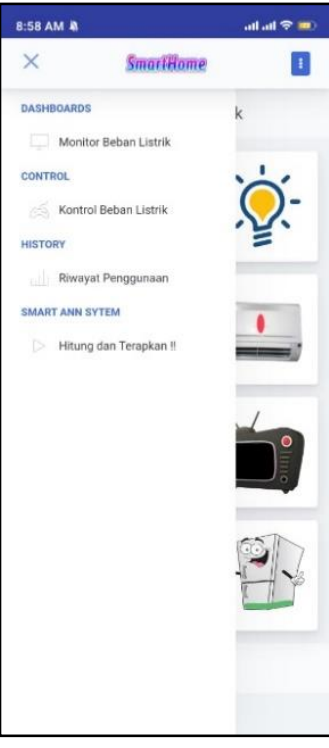

(c)

Gambar 5. a. Halaman login, b. Halaman monitoring, c. Pilihan menu utama 
JSAI : Journal Scientific and Applied Informatics

Vol. 4, No. 01, Januari 2021, hal. 1 10

E-ISSN: 2614-3054; P-ISSN: 2614-3062, accredited by Kemenristekdikti, Sinta 5

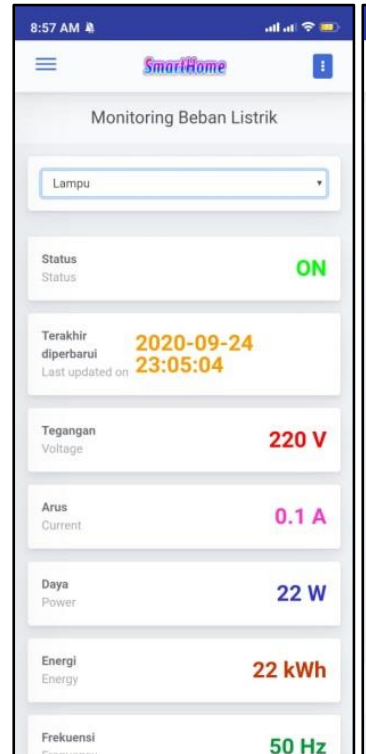

(a)

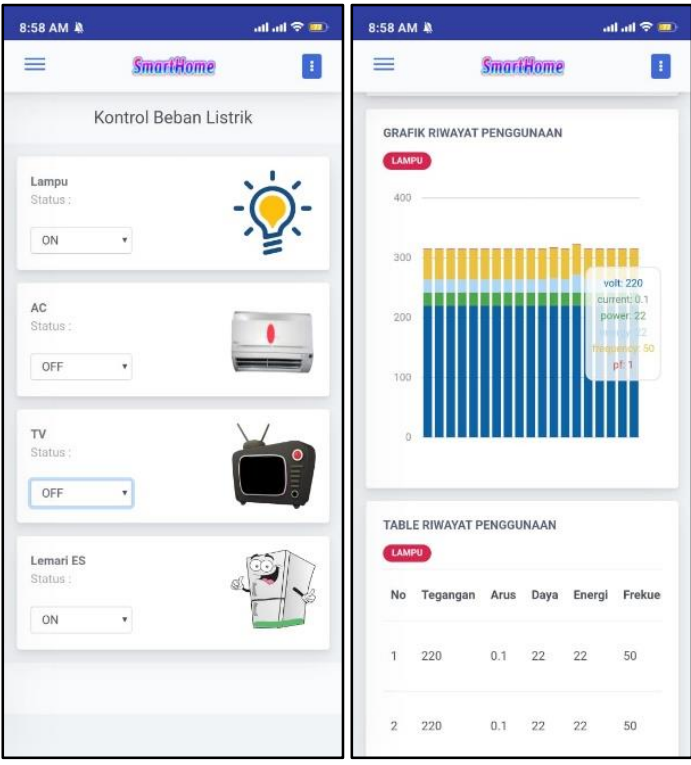

(b)

Gambar 6. a. Halaman monitoring detail komponen, b. halaman kontrol, c. halaman history

Untuk menjalankan sistem rekomendasi kecerdasan buatan, dapat dilakukan pada halaman Smart ANN System seperti ditunjukan pada Gambar 7a. Pengguna cukup memasukan nilai target tagihan dalam satu bulan. Parameter temperatur, rata-rata waktu pengggunaan ruangan per jam, dan intensitas cahaya akan ditampilkan secara otomatis berdasarkan data pengukuran oleh IoT Smart Meter + Relay. Selamat proses perhitungan akan tampil progress bar seperti pada Gambar 7b. Hasil keluaran system akan ditampilkan seperti pada Gambar 7c. Apabila rekomendasi yang diberikan sesuai dengan harapan pengguna, pengguna dapat menyimpan konfigurasi tersebut. Data durasi maksimal tersebut akan dikonversi oleh sistem ke dalam 30 hari, disimpan ke dalam database dan ditampilkan ke dalam Menu Monitoring seperti pada Gambar 7b sebelumnya.

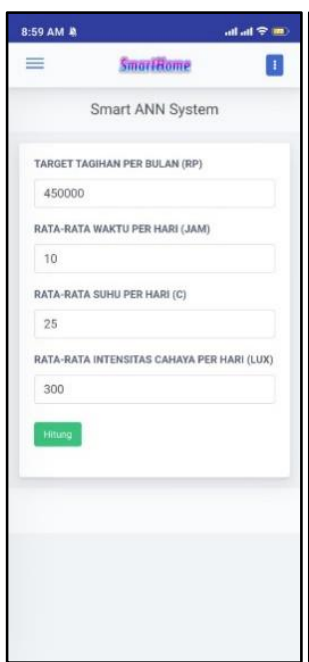

(a)

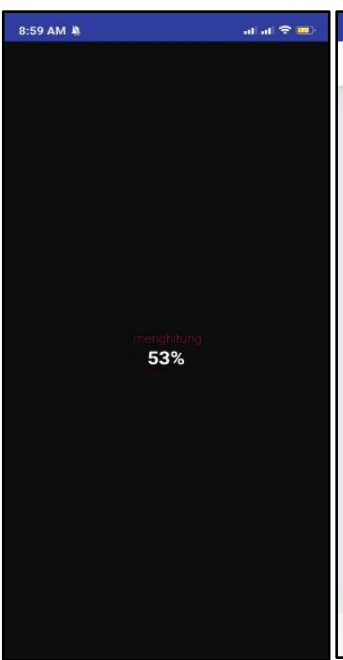

(b)

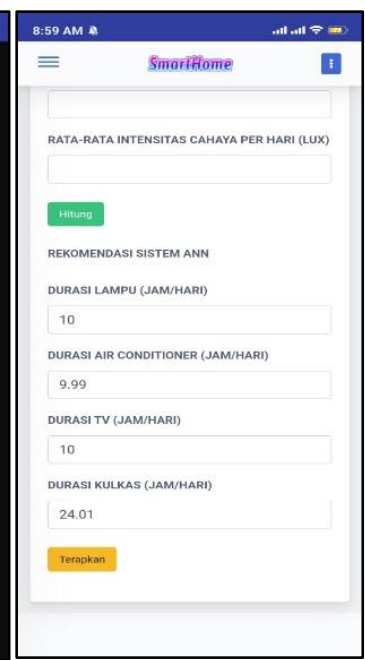

(c)

Gambar 7. Tampilan antarmuka halaman "Smart ANN System"

Aplikasi "RIS-Smart Home" tersebut sudah dilakukan pengujian verifikasi maupun validasi. Selain itu juga dilakukan pengujian dengan menggunakan metode Black Box. Metode Black Box diterapkan dengan memberikan berbagai skenario operasi maupun inputan data kepada aplikasi dan membandingkan dengan hasil keluaran. Hasil pengujian terhadap semua halaman aplikasi sesuai ditunjukan pada Tabel 4, aplikasi yang dibangun sudah $100 \%$ beroperasi sesuai dengan kondisi seharusnya. 
JSAI : Journal Scientific and Applied Informatics

Vol. 4, No. 01, Januari 2021, hal. 1 10

E-ISSN: 2614-3054; P-ISSN: 2614-3062, accredited by Kemenristekdikti, Sinta 5

DOI: 10.36085

Tabel 4. Pengujian Black Box Aplikasi

\begin{tabular}{lcc}
\hline Jenis Halaman & Jumlah Jenis Pengujian & Keterangan \\
\hline Login & 2 & $100 \%$ sesuai \\
Monitoring & 1 & $100 \%$ sesuai \\
Kontrol & 8 & $100 \%$ sesuai \\
Riwayat & 4 & $100 \%$ sesuai \\
Sistem ANN & 2 & $100 \%$ sesuai \\
\hline \multicolumn{2}{l}{} & \\
\hline
\end{tabular}

\subsection{Sistem ANN}

Untuk pengujian ANN dengan dimensi input/perceptron 1x4, dilakukan pengujian beberapa jumlah variasi neuron (weight matriks) dengan dimensi bias mengikuti dimensi hasil sebelumnya, dan variasi jumlah iterasi. Untuk data training diambil sample sebanyak 10. Pada Tabel 5 dapat dilihat nilai RMSE training terhadap 5 macam target uji.

Tabel 5. Pengujian Artificial Neural Network

\begin{tabular}{ccccccc}
\hline \multirow{2}{*}{ Iterasi } & \multicolumn{3}{c}{ RMSE Training } & \multicolumn{2}{c}{ RMSE Uji } \\
\cline { 2 - 4 } & $\begin{array}{c}\text { Jumlah } \\
\text { neuron 4 }\end{array}$ & Itersi Ke & $\begin{array}{c}\text { Jumlah } \\
\text { neuron 8 }\end{array}$ & Iterasi Ke & Jumlah & Jumlah \\
& $2,32 \%$ & 17611 & $2,986 \%$ & 19998 & $4,42 \%$ & $1,97 \%$ \\
\hline 20000 & $2,32 \%$ & 17611 & $2,859 \%$ & 24992 & $4,42 \%$ & $1,63 \%$ \\
25000 & $2,32 \%$ & 17611 & $2,652 \%$ & 29992 & $4,42 \%$ & $1,64 \%$ \\
30000 & &
\end{tabular}

Pada Tabel 5, nilai RMSE yang baik pada jumlah neuron 4 (weight $4 \mathrm{x} 4$ ) dengan kondisi iterasi 2000030000 menghasilkan RMSE yang sama sebesar 2,32\% dan RMSE uji pada kondisi bernilai 4,42 \%. Jika dilihat pada bagian tersebut kondisi RSME training mempunyai nilai yang sama dengan keadaan lokasi RMSE training berada pada perulangan 17611. Untuk RMSE training dengan jumlah neuron 8 (weigth $8 \times 4$ ) menghasilkan RMSE training yang lebih besar ketimbang ketika jumlah neuron 4 (weight $4 \times 4$ ) serta kondisi operasi komputasi dengan matriks yang lebih besar akan memakan waktu dan kapasitas memeri pada raspberry PI. Kondisi ini juga menghasilkan RMSE uji lebih besar dari matriks W 4x4. Untuk penelitian ini cukup dengan toleransi RMSE berada pada $\pm 5 \%$ yang bertujuan dalam mengoptimalkan proses komputasi[17]. Oleh karena itu untuk pengujian selanjutnya menggunakan iterasi 20000 dengan jumlah 4 neuron .

Sistem ANN tersebut telah mampu diintegrasikan dengan baik ke dalam aplikasi "RIS - Smart Home". Pengujian dilakukan sesuai dengan Tabel 6. Pada pengujian tersebut menggunaan parameter rata-rata waktu ruangan digunakan per hari sebesar $10 \mathrm{jam}$, rata-rata temperatur sebesar $23 \mathrm{C}$, rata-rata intensitas Cahaya sebesar 300 Lux, dan biaya listrik sebesar Rp 1.450 / kWh. Seperti ditunjukan pada Tabel VI, sistem sudah mampu terintegrasi dengan baik, antara target tagihan dengan perhitungan tagihan berdasarkan rekomendasi yang diberikan memiliki tingkat kesalahan sebesar $1.64 \%$.

Tabel 6. Pengujian Sistem ANN Terhadap Beberapa Skenario Tagihan Bulanan

\begin{tabular}{|c|c|c|c|c|c|c|}
\hline \multirow{2}{*}{ Target Tagihan } & \multicolumn{4}{|c|}{ Durasi Rekomendasi Sistem ANN (jam) } & \multirow{2}{*}{ Tagihan } & \multirow{2}{*}{ Error $(\%)$} \\
\hline & Lampu & $\mathbf{A C}$ & TV & Refrigerator & & \\
\hline Rp 100.000 & 0 & 0 & 0 & 24 & Rp 104.400 & $4.40 \%$ \\
\hline $\operatorname{Rp} 200.000$ & 9.55 & 1.83 & 4.88 & 24 & Rp 199.469 & $0.27 \%$ \\
\hline Rp 300.000 & 1.48 & 5.53 & 3.49 & 24 & Rp 307.654 & $2.55 \%$ \\
\hline $\operatorname{Rp} 400.000$ & 2.65 & 7.95 & 6.32 & 24 & Rp 400.570 & $0.14 \%$ \\
\hline Rp 500.000 & 10 & 10 & 10 & 24 & Rp 495.900 & $0.82 \%$ \\
\hline \multicolumn{6}{|c|}{ Rata-rata } & $1.64 \%$ \\
\hline
\end{tabular}

\section{KESIMPULAN}

Berdasarkan pengujian aplikasi menggunakan ANN ini, secara keseluruhan didapatkan bahwa sistem ini berjalan dengan baik dengan hasil tampilan program android berjalan $100 \%$. Untuk hasil pengujian keseluruhan program didapatkan nilai rata-rata error sebesar $1,64 \%$.

Error pada skenario tagihan bulan tergantung dari komputasi ANN yang mana nilai RMSE dengan kisaran $0,82 \%-4,5 \%$. Faktor yang mempengaruhi nilai RMSE tersebut adalah jumlah Iterasi, dan jumlah neuron yang digunakan. Hasil pengujian pada saat siklus training ANN menunjukkan jumlah neuron dan iterasi yang besar belum tentu menghasilkan RMSE yang kecil dan komputasi yang optimal. 


\section{UCAPAN TERIMA KASIH}

Terima kasih kami haturkan kepada Kementerian Riset dan Teknologi/Badan Riset dan Inovasi Nasional, Khususnya Deputi Bidang Penguatan Riset dan Pengembangan, yang telah mendanai penelitian ini dalam skema Penelitian Dosen Pemula (PDP) tahun 2020.

\section{REFERENSI}

[1] O.: Yona, A. Pembimbing, R. B. Ningsih, and N. Aqualdo, "PENGARUH PERTUMBUHAN EKONOMI DAN PENDUDUK TERHADAP KONSUMSI ENERGI DI INDONESIA The effect of economic and population growth of energy consumption in Indonesia," 2015.

[2] D. Kurnianto, A. M. Hadi, and E. Wahyudi, "Perancangan Sistem Kendali Otomatis pada Smart Home menggunakan Modul Arduino Uno," J. Nas. Tek. ELEKTRO, 2016, doi: 10.25077/jnte.v5n2.276.2016.

[3] . Z., . Z., and K. Amri, "Desain Sistem Kontrol Penyalaan Lampu dan Perangkat Elektronik untuk Meniru Keberadaan Penghuni Rumah," J. Nas. Tek. ELEKTRO, 2016, doi: 10.25077/jnte.v5n1.182.2016.

[4] M. Fajar Wicaksono, "IMPLEMENTASI MODUL WIFI NODEMCU ESP8266 UNTUK SMART HOME," 2017.

[5] S. N. Ishak, N. N. N. Abd Malik, N. M. Abdul Latiff, N. Effiyana Ghazali, and M. A. Baharudin, "Smart home garden irrigation system using Raspberry Pi," 2018, doi: 10.1109/MICC.2017.8311741.

[6] B. Zhou et al., "Smart home energy management systems: Concept, configurations, and scheduling strategies," Renewable and Sustainable Energy Reviews. 2016, doi: 10.1016/j.rser.2016.03.047.

[7] M. Alaa, A. A. Zaidan, B. B. Zaidan, M. Talal, and M. L. M. Kiah, "A review of smart home applications based on Internet of Things," Journal of Network and Computer Applications. 2017, doi: 10.1016/j.jnca.2017.08.017.

[8] Y. Goldberg, "Neural Network Methods for Natural Language Processing," Synth. Lect. Hum. Lang. Technol., 2017, doi: 10.2200/S00762ED1V01Y201703HLT037.

[9] K. Muralitharan, R. Sakthivel, and R. Vishnuvarthan, "Neural network based optimization approach for energy demand prediction in smart grid," Neurocomputing, 2018, doi: 10.1016/j.neucom.2017.08.017.

[10] E. Hodo et al., "Threat analysis of IoT networks using artificial neural network intrusion detection system," 2016, doi: 10.1109/ISNCC.2016.7746067.

[11] J. C. R. Whittington and R. Bogacz, "Theories of Error Back-Propagation in the Brain," Trends Cogn. Sci., vol. 23, no. 3, pp. 235-250, Mar. 2019, doi: 10.1016/j.tics.2018.12.005.

[12] M. T. Hagan, H. B. Demuth, and M. H. Beale, "Neural Network Design," Bost. Massachusetts PWS, 1995, doi: 10.1007/1-84628-303-5.

[13] Y. Ganin et al., "Domain-Adversarial Training of Neural Networks," Adv. Comput. Vis. Pattern Recognit., May 2015, doi: 10.1007/978-3-319-58347-1_10.

[14] B. Baker, O. Gupta, N. Naik, and R. Raskar, "Designing neural network architectures using reinforcement learning," 2017.

[15] T. Han, Y. Lu, S. C. Zhu, and Y. N. Wu, "Alternating back-propagation for generator network," 2017.

[16] Z. Ye and M. K. Kim, "Predicting electricity consumption in a building using an optimized backpropagation and Levenberg-Marquardt back-propagation neural network: Case study of a shopping mall in China," Sustain. Cities Soc., 2018, doi: 10.1016/j.scs.2018.05.050.

[17] Z. He, X. Zhang, Y. Cao, Z. Liu, B. Zhang, and X. Wang, "Litenet: Lightweight neural network for detecting arrhythmias at resource-constrained mobile devices," Sensors (Switzerland), 2018, doi: $10.3390 / \mathrm{s} 18041229$. 